OLIVEIRA IT; LOPES CA; MOURA AB. 2014. Fruit yield and bacterial wilt symptoms on eggplant genotypes grown in soil infested with Ralstonia solanacearum. Horticultura Brasileira 32: 453-457. DOI - http://dx.doi.org/10.1590/S0102-053620140000400013

\title{
Fruit yield and bacterial wilt symptoms on eggplant genotypes grown in soil infested with Ralstonia solanacearum
}

\section{Ivani T Oliveira ${ }^{1,2}$; Carlos A Lopes ${ }^{3}$; Andrea B Moura ${ }^{2}$}

${ }^{1}$ UFVJM-Depto. Agronomia, Rod. MGT 367 km 583, nº 5000, Alto da Jacuba, 39100-000 Diamantina-MG; ivani.teixeira@ufvjm.edu. br; ${ }^{2}$ UFPel-Depto. Fitossanidade, C. Postal 354, 96010-970 Pelotas-RS; abmoura@ufpel.tche.br; ${ }^{3}$ Embrapa Hortaliças, C. Postal 218, 70351-970 Brasília-DF; carlos.lopes@embrapa.br

\begin{abstract}
Fruit yield and bacterial wilt symptoms of eggplant genotypes CNPH006, CNPH171, CNPH658, CNPH778, CNPH783, and CNPH785 were quantified in soil naturally infested with Ralstonia solanacearum (race 1, biovar 3) in Brasília, Brazil. Except for CNPH778, all genotypes developed at least one typical wilted plant. Besides wilt, other symptoms considered for assessing levels of tolerance/resistance among genotypes were plant death (CNPH006, CNPH171, CNPH658 and CNPH783), leaf chlorosis (CNPH785) and plant dwarfing (all genotypes). The occurrence of bacterial ooze on cut stems was observed in all plants grown in infested beds, including those that did not exhibit wilt symptoms. Plants grown simultaneously in noninfested beds of the same dimensions and soil characteristics allowed the comparison of yield losses due to the pathogen. The genotypes were grouped according to their ability to maintain fruit production in the infested area. CNPH785 was the most tolerant genotype, with no significant loss due to the disease, followed by CNPH783, CNPH778 and CNPH171, with mean losses of $19.3 \%, 11.4 \%$, and $10.1 \%$, respectively. The genotypes CNPH658 and CNPH006 were the most susceptible, with average losses of 99.53 and $99.32 \%$, respectively.
\end{abstract}

Keywords: Solanum melongena, resistance, losses.

\section{RESUMO}

Produtividade e sintomas de murcha-bacteriana de genótipos de berinjela cultivados em solo infestado com Ralstonia solanacearum

A produção de frutos e sintomas de murcha-bacteriana foram quantificados nos genótipos de berinjela CNPH006, CNPH171, CNPH658, CNPH778, CNPH783 e CNPH785 cultivados em solo naturalmente infestado com Ralstonia solanacearum, raça 1, biovar 3 em Brasília-DF. Com exceção do genótipo CNPH778, todos os genótipos apresentaram pelo menos uma planta com murcha, sintoma típico da doença. Entretanto, para diferenciar níveis de resistência/ tolerância entre os genótipos, foram considerados, além da murcha, os sintomas: seca e morte de plantas (CNPH006, CNPH171, CNPH658 e CNPH783), amarelecimento de folhas (CNPH785) e menor crescimento de plantas (todos os genótipos). A ocorrência de fluxo bacteriano foi constatada em todas as plantas cultivadas nos canteiros infestados, inclusive naquelas que não apresentaram sintomas de murcha. Plantas cultivadas simultaneamente em canteiros não infestados, com as mesmas dimensões e características, permitiram obtenção de dados de produção em áreas infestadas e não infestadas. Os genótipos foram agrupados quanto à sua capacidade de manter a produção de frutos na área infestada. Quando comparados à média obtida na área livre do patógeno, CNPH785 foi o mais tolerante, não apresentando perda na produção, seguido dos genótipos CNPH783, CNPH778 e CNPH171, com perdas médias de 19,3; 11,4 e 10,1\%, respectivamente. Os genótipos CNPH658 e CNPH006 foram os mais suscetíveis, com perdas médias de 99,53 e 99,32\%, respectivamente.

Palavras-chave: Solanum melongena, murcha bacteriana, perdas.

\section{(Recebido para publicação em 23 de outubro de 2014; aceito em 13 de agosto de 2014) (Received on October 23, 2014; accepted on August 13, 2014)}

$\mathrm{T}$ he eggplant (Solanum melongena) is a solanaceous plant native to the tropical regions of Asia, grown for centuries by Chinese, Indians and Arabs. It was introduced in Brazil in the sixteenth century during the Portuguese colonization (Ribeiro, 2007).

In Brazil, the total volume of eggplant fruits traded has increased steadily in the last decades due to the disclosure of its value as a functional food, which, among several claimed benefits, acts on cholesterol lowering (Derivi et al., 2002). The crop area in São Paulo state, largest producer and consumer of eggplant, increased from 559 ha, in 1984 , to 1,946 ha, in 2008 , increasing the commercialization in the state from $15,534 \mathrm{t}$ to $51,185 \mathrm{t}$ (IEA/ CATI-SAAESP, 2010). Minas Gerais,
Paraná and Distrito Federal are the other largest eggplant producers (Ribeiro, 2007).

Eggplant yields in Brazil reach 30 to $65 \mathrm{t} / \mathrm{ha}$ in the field and 60 to $95 \mathrm{t} /$ ha in protected environments (Moreira et al., 2006). The preference of the Brazilian market is for the dark purple, bright, oblong and green-stalked fruit (Ribeiro, 2007). Currently, local market 
is dominated by hybrids due to their productivity characteristics, resistance to diseases and pests, uniformity and fruit quality (Antonini et al., 2002).

The occurrence of bacterial wilt, caused by Ralstonia solanacearum, is one of the limiting factors for growing solanaceous crops in warm and humid climates, such as in the Amazon Region. The local production is practically restricted to smallholder's gardens which, after a few successive crops, are no longer suitable for growing many vegetables, especially solanaceous. For instance, losses of up to $40 \%$ due to bacterial wilt were reported in a commercial eggplant field in the state of Amazon (Coelho-Netto et al., 2004). The disease also has a surmount importance for the cultivation of solanaceous in the Northeastern and Mid-Western lowland regions (Takatsu \& Lopes, 1997).

The most typical symptom of bacterial wilt of eggplant is a wilt starting from the upper parts of the plant, observed initially in the warmer periods of the day, with leaf turgidity often recovering overnight in cooler or rainy days. If favorable environmental conditions prevail, diseased plants complete wilt and die (Ribeiro, 2007; Lopes, 2009). Leaf epinasty and adventitious root formation due to the imbalance in the levels of auxin and ethylene eventually occur (Buddenhagen \& Kelman, 1964).

Ralstonia solanacerum enters the plant through mechanical wounds or micro-wounds caused by the growth of secondary roots, followed by xylem invasion (Vasse et al., 1995). Xylem colonization induces partial or complete mechanical blockage of the water transport from the roots to the top of the plant. The formation of tyloses and the increased levels of ethylene and abscisic acid are associated to the infection process (Kelman, 1953). Xylem vessels can hold concentration above $10^{10}$ cells per centimeter of susceptible tomato stem which, with extracellular polysaccharides produced by the pathogen, increase the sticky consistence of the xylem fluid, hindering its flow toward the leaves, thus causing wilting and the death of the plant
(Genin \& Boucher, 2002). After plant death, the bacterium infects the soil where it survives saprophytically and infects new plants (Genin \& Boucher, 2002). Extracellular polysaccharides produced by the pathogen, besides forming biofilms on the surface of the xylem during disease development, also prevent desiccation or antibiosis in the absence of a host plant, what partially explains the long survival of the pathogen in the soil (Milling et al., 2011; Hikichi et al., 2007; Genin \& Boucher, 2002).

When compared to other solanaceous hosts, eggplant is not as susceptible to bacterial wilt as potatoes, tomatoes and bell peppers. Under less favorable conditions for the disease, plants may not wilt, but grow more slowly than the healthy ones (Ribeiro, 2007). Therefore, when classical symptoms of bacterial wilt are not observed, diagnosis of the disease and the selection of resistant genotypes can be complicated.

Despite the large amount of work on bacterial wilt, reports that estimate yield losses due to this disease under natural soil infestation are scarce, especially considering the variability of resistance on host plants. The criterion mostly used to quantify the resistance is the survival rate under infection pressure, but, in almost all cases, the latent infection or colonization is not taken into account (Boshou, 2005). In greenhouse tests, eggplant genotypes reported as resistant to bacterial wilt based on the wilting characteristic, displayed different symptoms, including dwarfism, suggesting that yield losses in the field are real also for nonwilting plants (Morgado, 1991; Oliveira, 2011).

The objective of this work was to evaluate, in a soil naturally infested by $R$. solanacearum, the plant growth, the bacterial wilt symptoms and the yield capacity of eggplant genotypes previously identified as resistant to bacterial wilt in the greenhouse.

\section{MATERIAL AND METHODS}

The experiments were carried out from September 1999 to March 2000 at Embrapa Hortaliças, Brasilia, Brazil, where the average monthly rainfall was $154.7 \mathrm{~mm}$ and mean temperature of $23.9^{\circ} \mathrm{C}$. The experimental plots consisted of a set of $10 \times 1 \mathrm{~m}$ beds surrounded by a $15 \mathrm{~cm}$ high borders. Part of the beds, originally used for seedling production, was built on a soil spot naturally infested with $R$. solanacearum race 1 , biovar 3 . In order to improve the uniform infestation of the soil of each of five beds, three rows of tomato seedlings 'Ponderosa', susceptible to bacterial wilt, were transplanted spaced $25 \times 25 \mathrm{~cm}$. Prior to planting, the soil of the five infested and five noninfested beds were analyzed, treated with a soil insecticide, corrected with dolomitic lime and fertilized with NPK (10-10-10) and cow manure, according to the recommendation for tomato (CFSEMG, 1989). After 30 days of transplanting, all the tomato plants in the infested beds showed symptoms of bacterial wilt and were mechanically incorporated into the soil.

Thirty days after bed preparation, which included weekly sprinkler irrigation to maintain the soil slightly humid, seedlings of eggplant grown in polystyrene trays with sterilized substrate, 35 days after sowing, were transplanted in rows $50 \mathrm{~cm}$ apart and $80 \mathrm{~cm}$ between plants. In each infested and noninfested bed, four plants of six genotypes with different levels of susceptibility to $R$. solanacearum were transplanted (Table 1). The plants were irrigated with a micro sprinkler to keep the soil moisture close to field capacity.

The experimental design consisted of randomized blocks with five replications, each bed being a block. Analyses of variance were used to compare the performance of the six eggplant genotypes in the infested beds with the statistical program Winstat 1.0 (Machado \& Conceição, 2005). In this same application, the residual analysis to verify the assumptions of the analysis of variance was also performed: box plot, normal distribution and dispersion error.

Mean yield of genotypes were compared by Tukey test $(\mathrm{p} \leq 0.05)$. The yield reduction of each genotype was calculated in relation to the mean yield of the respective genotypes upon simultaneous cultivation in the four 
noninfested beds. The Scott-Knott group test $(\mathrm{p} \leq 0.05)$ was performed for this comparison using GENES software (Cruz, 2006).

The ordinary bacterial wilt symptoms expected for eggplant infection, i.e. yellowing, dwarfism, wilting, and death, were observed during crop cycle upon weekly monitoring up to 130 days after transplanting. Fruit production (kg/plant) of each plot was taken in five harvests, started 70 days after transplanting with an interval of 15 days between harvests. Wilted plants were sampled in order to certify the causal agent of the disease. After the last harvest, all the remaining plants of the two areas were cut and stem fragments were removed $5 \mathrm{~cm}$ above the soil line for observing the bacterial flow oozing out from the stem in a glass, to confirm the bacterial etiology (Lopes \& Quezado-Soares, 1997). Bacterial isolation was performed in Kelman's culture medium with tetrazolium, in which $R$. solanacearum colonies can be partially identified after cultivation for 48 hours at $28^{\circ} \mathrm{C}$ (Kelman, 1954). Fluidal colonies with red centers and white edges, typical of this bacterium in Kelman's medium, were transferred to new plates containing the same medium devoid of tetrazolium to allow faster growth. Putative colonies of $R$. solanacearum were submitted to biochemical tests to determine the biovar, according to the ability to oxidize sole carbon sources in a minimal medium (Hayward, 1991). The isolates obtained and identified were stored in tubes with sterile water at room temperature.

\section{RESULTS AND DISCUSSION}

Symptoms associated to bacterial wilt developed only in plants cultivated in infested beds. The typical wilting was first observed 10 days after transplant in genotypes CNPH006 and CNPH658. Except for CNPH778, all genotypes yielded at least one wilted plant (Table 2). Evolution from wilting to plant death was observed in genotypes CNPH006, CNPH171, CNPH783 and CNPH658, and leaf chlorosis in CNPH785. Plant

Table 1. Set of Solanum melongena genotypes and their previously known reactions ${ }^{1}$ to Ralstonia solanacearum strains (procedência e reações ${ }^{1}$ a três estirpes de Ralstonia solanacearum de genótipos de Solanum melongena). Brasília, Embrapa Hortaliças, 2000.

\begin{tabular}{lcccc}
\hline \multirow{2}{*}{ Genotype } & \multirow{2}{*}{ Origin } & \multicolumn{3}{c}{$\boldsymbol{R}$. solanacearum strains } \\
\cline { 3 - 5 } & & CNPH56 $^{2}$ & CNPH19 $^{3}$ & CNPH152 $^{3}$ \\
\hline CNPH006 & Agroflora (Brazil-SP) & $\mathrm{R}$ & $\mathrm{S}$ & $\mathrm{R}$ \\
CNPH171 & INRA (France) & $\mathrm{HR}$ & $\mathrm{S}$ & $\mathrm{R}$ \\
CNPH658 & Topseed (USA) & $\mathrm{S}$ & $\mathrm{S}$ & $\mathrm{S}$ \\
CNPH778 & AVRDC (India) & nd & $\mathrm{HR}$ & $\mathrm{HR}$ \\
CNPH783 & AVRDC (Indonesia) & nd & $\mathrm{S}$ & $\mathrm{HR}$ \\
CNPH785 & AVRDC (India) & nd & HR & $\mathrm{R}$ \\
\hline
\end{tabular}

${ }^{1} \mathrm{HR}$ : high resistance ; R: intermediate resistance; S: susceptible; nd: not determined (HR: resistência elevada; R: resistência intermediária; S: suscetível; nd: não determinado); Biovar 3. Fonte: Morgado, 1991; ${ }^{3}$ Biovar 1. Fonte: Oliveira, 2011)

Table 2. Wilt Incidence (W) and plant death (D) in eggplant genotypes at 10, 50, 90 and 130 days after transplanting to beds naturally infested with Ralstonia solanacearum, race 1, biovar 3 [incidência (\%) de sintoma de murcha (W) e morte (D) em plantas de genótipos de berinjela, aos 10, 50, 90 e 130 dias após transplante em área infestada naturalmente com Ralstonia solanacearum, raça 1, biovar 3]. Brasília, Embrapa Hortaliças, 2000.

\begin{tabular}{|c|c|c|c|c|c|c|c|c|}
\hline \multirow{3}{*}{ Genotype } & \multicolumn{8}{|c|}{ Days after transplant } \\
\hline & \multicolumn{2}{|c|}{10} & \multicolumn{2}{|c|}{50} & \multicolumn{2}{|c|}{90} & \multicolumn{2}{|c|}{130} \\
\hline & $\mathbf{W}$ & $\mathbf{D}$ & $\mathbf{W}$ & $\mathbf{D}$ & $\mathbf{W}$ & $\mathbf{D}$ & $\mathbf{W}$ & D \\
\hline CNPH658 & 5 & 0 & 55 & 5 & 100 & 90 & 100 & 100 \\
\hline CNPH006 & 10 & 0 & 85 & 0 & 100 & 90 & 100 & 95 \\
\hline CNPH171 & 0 & 0 & 0 & 0 & 5 & 5 & 15 & 5 \\
\hline CNPH778 & 0 & 0 & 0 & 0 & 0 & 0 & 0 & 0 \\
\hline CNPH783 & 0 & 0 & 0 & 0 & 15 & 10 & 10 & 10 \\
\hline CNPH785 & 0 & 0 & 5 & 5 & 10 & 5 & 10 & 10 \\
\hline
\end{tabular}

Table 3. Yields (kg/plant) of eggplant genotypes cultivated in soils noninfested and infested with Ralstonia solanacearum, race 1, biovar 3 \{produção ( $\mathrm{kg}$ de frutos/planta sobrevivente) de genótipos de berinjela em área livre e em área infestada por Ralstonia solanacearum, raça 1, biovar 3$\}$. Brasília, Embrapa Hortaliças, 2000.

\begin{tabular}{|c|c|c|c|}
\hline \multirow{3}{*}{$\begin{array}{l}\text { Genotype } \\
\text { CNPH658 }\end{array}$} & \multicolumn{3}{|c|}{ Yield $^{1}$} \\
\hline & Noninfested & \multicolumn{2}{|c|}{ Infested } \\
\hline & $3.66 \quad b c$ & 0.17 & $\mathrm{~d}$ \\
\hline CNPH006 & $6.16 \mathrm{a}$ & 0.41 & d \\
\hline CNPH171 & 3.14 & 2.82 & \\
\hline CNPH778 & $5.28 \mathrm{a} \mathrm{b}$ & 4.68 & \\
\hline CNPH783 & $2.70 \quad \mathrm{c}$ & 2.18 & $\mathrm{c}$ \\
\hline CNPH785 & 1.98 & 2.08 & $\mathrm{c}$ \\
\hline $\mathrm{CV}(\%)$ & 22.12 & 15.80 & \\
\hline
\end{tabular}

${ }^{1}$ Means of five replicates; Means followed by the same letter on columns do not differ by Tukey test ( $\mathrm{p} \leq 0.05$ ) [médias de 5 repetições; Valores na coluna seguidos pelas mesmas letras não diferem pelo teste de Tukey $(\mathrm{p} \leq 0,05)]$.

dwarfism was present in all genotypes when compared to controls cultivated in noninfested beds.
The bacterial exudation tests indicated the presence of xylemassociated bacteria in the remaining 


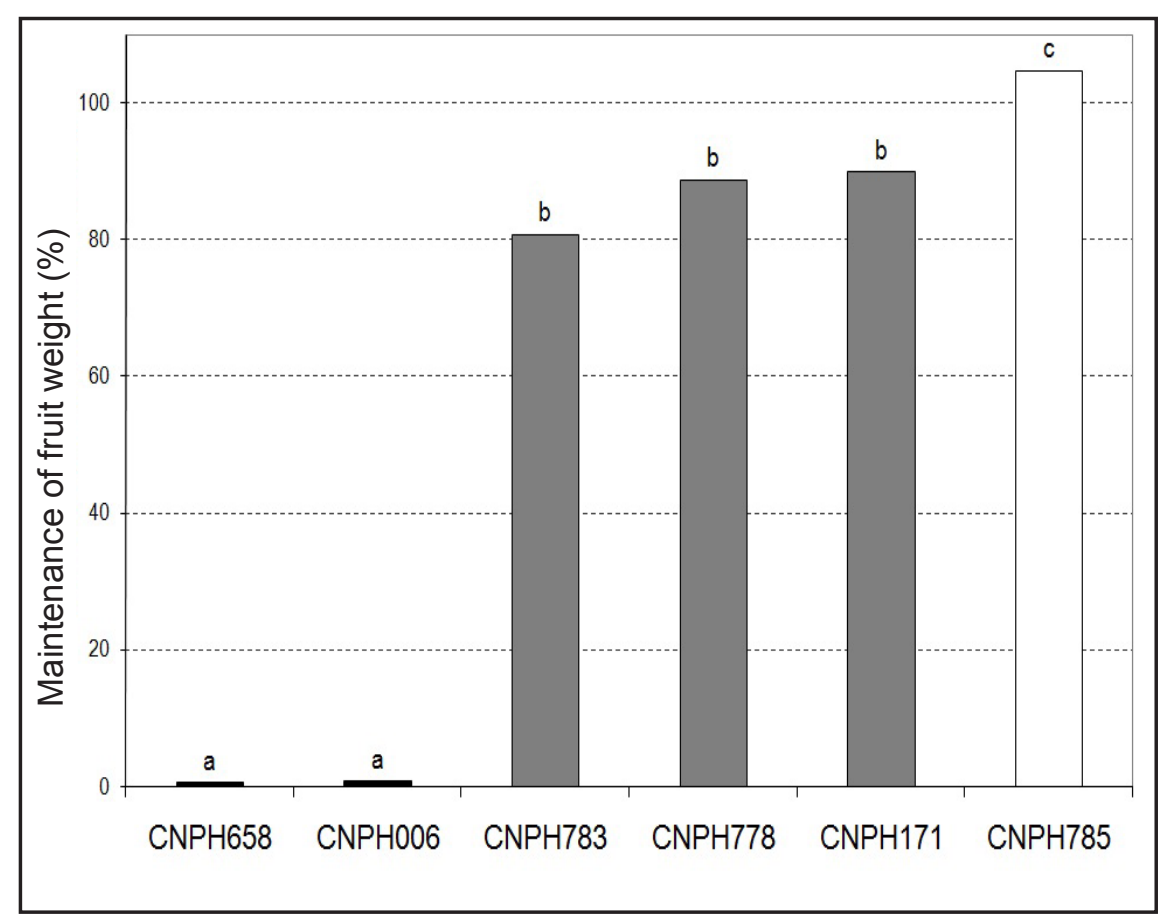

Figure 1. Fruit yield maintenance (\%) on eggplant genotypes grown in soil naturally infested with Ralstonia solanacearum, race 1, biovar 3, in relation to yield mean in noninfested soil. Columns topped by the same letters formed a group that does not differ by Scott-Knott clustering test $(\mathrm{p} \leq 0.05)$ \{manutenção na produção de frutos $(\%)$ de genótipos de berinjela cultivados em solo naturalmente infestado por Ralstonia solanacearum, raça 1, biovar 3, em relação à média de produção em solo livre do patógeno. As colunas com mesmas letras, no topo, formam grupos que não diferiram entre si, segundo o teste de agrupamento de ScottKnott $(\mathrm{p} \leq 0,05)\}$. Brasília, Embrapa Hortaliças, 2000.

plants of all genotypes cultivated in the infested beds only, even in symptomless plants. Wang et al. (1998) also observed latent infection in symptomless plants when assessing eggplant accesses for resistance to bacterial wilt.

Bacterial colonies were isolated from fragments of stems that displayed exudation. Biochemical tests consistently indicated the presence of $R$. solanacearum race 1 , biovar 3 , and one isolate of this pathogen was deposited in the collection maintained at Embrapa Hortaliças, identified as CNPH182. No attempts were made to isolate the bacterium from the noninfested beds, since no symptoms and no oozing were observed up to the end of the experiment.

The best fruit yields in the noninfested beds were obtained with genotypes CNPH006 and CNPH778 whereas, in the infested beds, with CNPH778. However, the genotype CNPH785 showed the lowest yield reduction when yields in noninfested and infested beds and eggplant is dependent on biovar and isolate of the pathogen (Lopes \& Boiteux, 2004; Lopes et al. 1994; Wicker et al., 2007; Coelho Netto et al., 2004; Gopalakrishnan et al., 2005; Gousset et al., 2005; Grimault \& Prior, 1994; Milling et al., 2011).

The genotype CNPH658 (Florida Market) was confirmed as a good susceptible control for studies on eggplant bacterial wilt resistance or on the pathogen's isolate virulence, as suggested by Morgado (1991). In contrast, CNPH006, which, in greenhouse tests by Morgado (1991) and Oliveira (2011) showed variable results and strain-dependent response, was as susceptible as the genotype CNPH658 in our experiments. However, its high yield, dark color and elongated fruit, which are the characteristics demanded by the Brazilian market, makes this genotype be considered as a recurrent parent in a future breeding work.

CNPH778 was the most resistant genotype in our trials given by disease incidence readings, but presented yield reduction in the infested as compared to noninfested beds (Table 2). Despite this reduction, it was the most productive genotype in the infested beds. The genotype CNPH785, despite being infected by $R$. solanacearum and displaying wilting, leaf chlorosis and plant dwarfism when grown in the infested beds, yielded the same fruit weight as in the noninfested beds, therefore indicating tolerance to the disease. Bacterial wilt tolerance was also described by Gousset et al. (2005) in Solanum torvum genotypes collected in Java.

Gousset et al. (2005), in studies on resistance in $S$. torvum, conjectured that the resistance of some genotypes to $R$. solanacearum could occur by limiting the multiplication or spread of the bacterial population in the stem. In fact, Oliveira (2011) quantified the multiplication rate of two $R$. solanacearum isolates in the stem of the CNPH778 and CNPH785, and found that the colonization in these genotypes was lower when compared to more susceptible genotypes, CNPH658 and CNPH171. The two resistancerelated mechanisms, by supporting higher population of the pathogen 
without yield loss (tolerance) or by depriving the bacterium to multiply or spread in the host, both of quantitative genetic control, can be exploited by plant breeders to fight the bacterial wilt disease in eggplants.

\section{REFERENCES}

ANTONINIACC; ROBLES WGR; TESSARIOLI NETO J; KLUGE RA. 2002. Capacidade produtiva de cultivares de berinjela. Horticultura Brasileira 20: 646-648.

BOSHOU L. 2005. A broad review and perspective on breeding for resistance to bacterial wilt. In: ALLEN C; PRIOR P; HAYWARD A (eds). Bacterial wilt disease and the Ralstonia solanacearum species complex. St Paul: APS Press. p. 225-246.

BUDDENHAGEN I; KELMAN A. 1964. A. Biological and physiological aspects of bacterial wilt caused by Pseudomonas solanacearum. Annual Review of Phytopathology 2: 203-230.

CFSEMG - Comissão de Fertilidade do Solo do Estado de Minas Gerais. 1989. Recomendações para uso de corretivos e fertilizantes em Minas Gerais: $4^{a}$. aproximação. Lavras. 159p.

COELHO NETTO RA; PEREIRA BG; NODA H; BOHER B. 2004. Murcha bacteriana no estado do Amazonas, Brasil. Fitopatologia Brasileira 29: 21-27.

CRUZ CD. 2006. Programa genes: biometria. Viçosa: UFV. 382p.

DERIVI SCN; MENDEZ MHM; FRANCISCONI AD; SILVA CS; CASTRO AF; LUZ DP. 2002. Efeito hipoglicêmico de rações à base de berinjela (Solanum melongena,L.) em ratos. Ciênc. Tecnol. Aliment. 22: 164-169.

GENIN S; BOUCHER C. 2002. Ralstonia solanacearum: secrets of a major pathogen unveiled by analysis of its genome. Molecular Plant Pathology 3: 111-118.

GOPALAKRISHNAN TR; SINGH PK; SHEELA KB; SHANKAR MA; KUTTY PCJ; PETER, KV. 2005. Development of bacterial wilt resistant varieties and basis of resistance in eggplant (Solanum melongena). In: ALLEN C; PRIOR P; HAYWARD A (eds). Bacterial wilt disease and the Ralstonia solanacearum species complex. St Paul: APS Press. p.
293-300.

GOUSSET C; COLLONNIE C; MULYA K; MARISKA I; ROTINO GL; BESSE P; SERVAES A; SIHACHAKR D. 2005. Solanum torvum as a useful source of resistance against bacterial and fungal diseases for improvement of eggplant (Solanum melongena). Plant Science 168: 319-327.

GRIMAULT V; PRIOR P. 1994. Invasiveness of Pseudomonas solanacearum in tomato, eggplant and pepper: a comparative study. European Journal of Plant Pathology 100: 259-267.

HAYWARD AC. 1991. Biology and epidemiology of bacterial wilt caused by Pseudomonas solanacearum. Annual Review of Phytopatholology 29: 65-87.

HIKICHI Y; YOSHIMOCHI T; TSUJIMOTO S; SHINOHARA R; NAKAHO K; KANDA A; KIBA A; OHNISHI K. 2007. Global regulation of pathogenicity mechanism of Ralstonia solanacearum. Plant Biotechnology 24: 149-154.

IEA/CATI - SAAESP. Banco de dados do Instituto de Economia Agrícola da Secretaria de Agricultura e Abastecimento do Estado de São Paulo. Disponível em http://ciagri.iea. sp.gov.br/bancoiea/Subjetiva_Imprimir.aspx. Acessado em 06 de fevereiro de 2010.

KELMAN A. 1953. The bacterial wilt caused by Pseudomonas solanacearum: a literature review and bibliography. North Carolina Agricultural Experimental Station (Technical Bulletin 99). 194p.

KELMAN A. 1954. The relationship of pathogenicity in Pseudomonas solanacearum to colony appearance on a tetrazolium medium. Phytopathology 44: 693-695.

LOPES CA. 2009. Murcha bacteriana ou murchadeira - uma inimiga do tomateiro em climas quentes. Brasília: Embrapa Hortaliças. $7 \mathrm{p}$.

LOPES CA; BOITEUX LS. 2004. Biovar-specific and broad-spectrum sources of resistance to bacterial wilt (Ralstonia solanacearum) in Capsicum. Crop Breeding and Applied Biotechnology 4: 350-355.

LOPES CA; QUEZADO-SOARES AM; MELO PE. 1994. Differential resistance of tomato cultigens to biovars I and III of Pseudomonas solanacearum. Plant Disease 78: 1091-1094.

LOPES CA; QUEZADO-SOARES AM. 1997. Doenças bacterianas das hortaliças: diagnose e controle. Brasília: Embrapa/SPI. 70 p.
MACHADO A; CONCEIÇÃO AR. 2005. Programa estatístico WinStat: sistema de análise estatístico para Windows, versão Beta. Pelotas: UFPel.

MILLING A; BABUJEE L; ALLEN C. 2011. Ralstonia solanacearum extracellular polysaccharide is a specific elicitor of defense responses in wilt-resistant tomato plants. PlosOne 6: e15853. doi:10.1371/journal. pone.0015853. Disponível em http://www. plosone.org/article/info:doi/10.1371/journal. pone.0015853. Acessado em 12 de julho de 2012.

MOREIRA SR; TRANI PE; TIVELLI SW; LEITE D. 2006. Berinjela: Solanum melongena. Disponível em: http://www.iac.sp.gov.br/ Tecnologias/Berinjela/BERINJELA.htm. Acessado em 26 de julho de 2008.

MORGADO HS. 1991. Resistência de berinjela (Solanum melongena) à murcha-bacteriana causada por Pseudomonas solanacearum. Brasilia: UnB. 88p (Tese mestrado).

OLIVEIRA IT. 2011. Caracterização da resistência de genótipos de berinjela à murcha bacteriana. Pelotas: UFPel. 82p (Tese doutorado).

RIBEIRO CSC (ed). 2007. Berinjela (Solanum melongena L.) Sistemas de produção, 3, Disponível em: http://sistemasdeproducao. cnptia.embrapa.br/FontesHTML/ Beringela/ Beringela_Solanum_melongena_L/index. html. Acessado em 20 de abril de 2013.

TAKATSU A; LOPES CA. 1997. Murchabacteriana em hortaliças: avanços científicos e perspectivas de controle. Horticultura Brasileira 15: 170-177.

VASSE J; FREY P; TRIGALET A. 1995. Microscopic studies of intercellular infection and protoxylem invasion of tomato roots by Pseudomonas solanacearum. Molecular Plant-Microbe Interactions 8: 241-251.

WANG JF; CHEN NC; LI HM. 1998. Resistance sources to bacterial wilt in eggplant. In: PRIOR P; ALLEN C; ELPHINSTONE J. (eds). Bacterial Wilt Disease, Molecular and Ecological Aspects. Berlin: Springer-Verlag. p. 284-289.

WICKER E; GRASSART L; CORANSONBEAUDU R; MIAN D; GUILBAUD C; FEGAN M; PRIOR P. 2007. Ralstonia solanacearum strains from Martinique (French West Indies) exhibiting a new pathogenic potential. Applied Environmental Microbiology 73: 6790-6801. 